Review

\title{
Aptasensors for Small Molecule Detection
}

\author{
Johanna-Gabriela Walter ${ }^{\mathrm{a}}$, Alexandra Heilkenbrinker ${ }^{\mathrm{a}}$, Jonas Austerjost ${ }^{\mathrm{a}}$, Suna Timur ${ }^{\mathrm{b}}$, \\ Frank Stahl ${ }^{\mathrm{a}}$, and Thomas Scheper ${ }^{\mathrm{a}}$ \\ a Gottfried Wilhelm Leibniz Universität Hannover, Institut für Technische Chemie, Callinstr. 5, \\ 30167 Hannover, Germany \\ b Ege University, Faculty of Science, Biochemistry Department, 35100 Bornova, Izmir, Turkey \\ Reprint requests to Dr. Johanna-Gabriela Walter. Fax: +49 5117623004. \\ E-mail: walter@iftc.uni-hannover.de
}

Z. Naturforsch. 2012, 67b, 976-986 / DOI: 10.5560/ZNB.2012-0147

Received May 31, 2012

Dedicated to Professor Heribert Offermanns on the occasion of his $75^{\text {th }}$ birthday

Aptamers are single-stranded oligonucleotides composed of RNA or DNA that are able to bind their corresponding targets via molecular recognition. Thus, aptamers can be thought of as nucleic acidbased alternatives to antibodies and have attracted attention as receptors in biosensors. Aptamers seem to be ideal biological recognition elements, since they enable the design of intelligent sensors based on their specific properties. Especially the fact that most aptamers undergo conformational changes during the binding of the target and their oligonucleotide nature can be used to rationally design novel sensing strategies. This review focuses on aptasensors for the detection of small molecules. In the first part, aptamers, their generation and their properties are briefly described. In the second part, different design strategies for aptasensors are reviewed, and examples for the detection of small molecules are given.

Key words: Small Molecule, Aptamer, Biosensor, Aptasensor

\section{Table of Contents}

1. Introduction

2. Aptamers

2.1. Selection of aptamers

2.2. Properties of aptamers

3. Aptasensors for Small Molecule Detection 3.1. Aptasensors based on target-induced structure switching

3.2. Aptasensors based on target-induced dissociation

3.3. Aptasensors based on competitive replacement

3.4. Aptasensors of sandwich-type

3.5. Aptasensors based on target-induced reassembly of aptamer fragments

4. Current Limitations and Future Perspectives

5. Summary and Conclusion

\section{Introduction}

The sensitive and specific detection of small molecules remains to be a challenging task. The most widely used method for the detection and quantifi- cation of small molecules is high-performance liquid chromatography (HPLC) with UV and/or fluorescence detection [1]. These methods have several disadvantages: They are laborious, and the extraction and cleanup processes of the columns is time-consuming. More sensitive and specific assays for the rapid detection of small molecules are needed. Biosensors for the detection of small analytes have been rapidly developed in the past decades and seem to satisfy the demands for timely and sensitive detection. This review focuses on aptasensors, a special class of biosensors utilizing aptamers as an element for molecular recognition. In the first part of the review aptamers, their generation and their properties are briefly described. In the second part, a review of the literature is given with focuses on small molecule analytes and the different possible design strategies for aptasensors.

\section{Aptamers}

Aptamers are single-stranded oligonucleotides composed of RNA or DNA generated by in vitro selection

(c) 2012 Verlag der Zeitschrift für Naturforschung, Tübingen · http://znaturforsch.com 


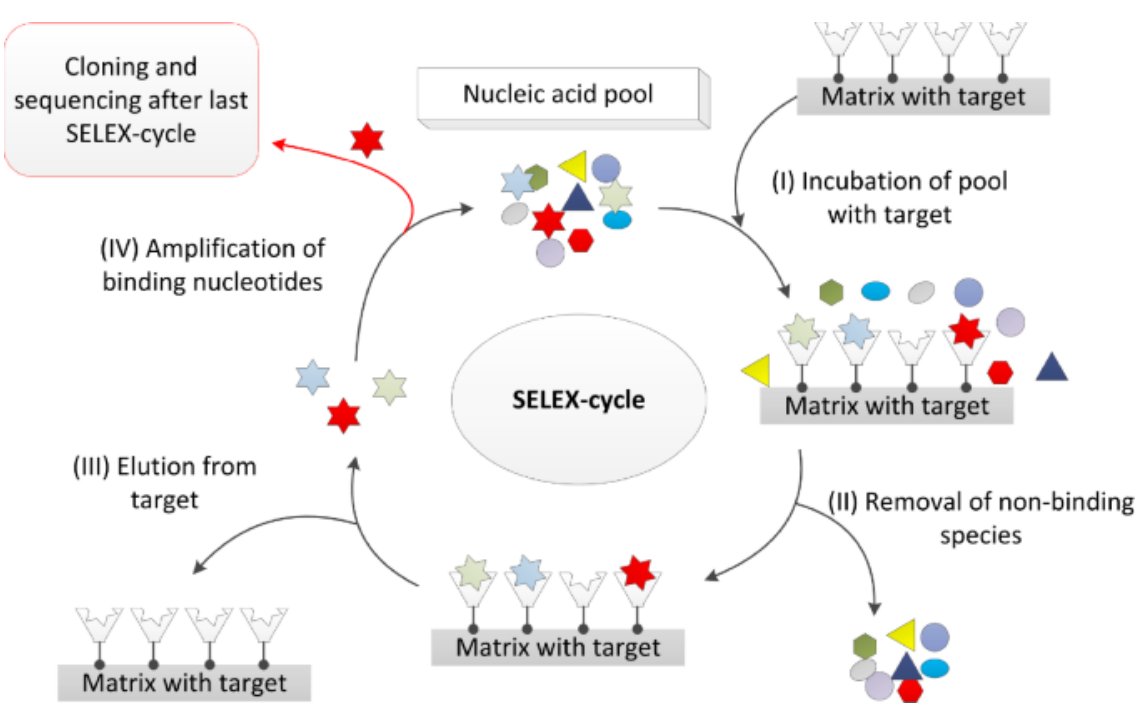

Fig. 1 (color online). Schematic illustration of the generation of aptamers via systematic evolution of ligands by exponential enrichment (SELEX). Modified from Proske et al. [8]. techniques (described in Section 2.1). Aptamers are able to fold into well-defined three-dimensional structures that enable the binding of a corresponding target via molecular recognition. Thus, aptamers can be thought of as a nucleic acid-based alternative to antibodies. Aptamers have already been selected as a probe for proteins, viruses, cells, as well as small molecules like vitamins, organic dyes, antibiotics, amino acids, nucleotides, and peptides [2].

\subsection{Selection of aptamers}

Aptamers can be generated by an in vitro selection technique termed systematic evolution of ligands by exponential enrichment (SELEX) [3-5]. During SELEX, aptamers are isolated from combinational libraries of synthetic oligonucleotides with regard to their affinity towards a given target molecule. Therefore, in a typical SELEX process (Fig. 1), the target is immobilized on a solid support like magnetic beads [6]. The oligonucleotides of the combinational library consist of a randomized region flanked by primer binding sites of known sequences. Frequently, the random region contains 40 nucleotides. Theoretically, this library can contain $4^{40}$ individual sequences; in practice $10^{14}-10^{15}$ individual sequences can be found [7]. During the incubation of the library with the target, a small proportion of the sequences is able to bind to the target, and non-binding sequences are removed. The binding sequences are eluted from the target and amplified by PCR. The resulting pool of enriched and amplified binders is employed as starting material of a subsequent SELEX cycle.

Typically, 8-16 SELEX cycles are applied to select aptamers with appropriate affinity towards the target. After selection, the final pool of oligonucleotides, which is composed of several aptamers directed against the target, is cloned and sequenced. Finally, the aptamers can be produced chemically by solid-phase synthesis.

While SELEX represents an iterative process of selection and amplification, more recently other techniques have been developed to obtain aptamers by one-step procedures including MonoLEX [9] and nonequilibrium capillary electrophoresis of equilibrium mixtures [10].

\subsection{Properties of aptamers}

Aptamers were shown to have dissociation constants in the nanomolar or even picomolar range and to bind their target with high specificity. The binding between the aptamer and the target is based on hydrogen bonding, hydrophobic and electrostatic interactions and steric effects [11]. In case of a protein target, the complementarity of the surfaces of target and aptamer contributes to the binding. In contrast, small molecule targets are often bound in a narrow binding pocket deep within the structure of the aptamer. 
Table 1. Differences between antibodies and aptamers and their consequences for the development of aptasensors. Adapted and extended from Walter et al. [16].

\begin{tabular}{|c|c|c|}
\hline Antibody & Aptamer & Consequences for aptasensor development \\
\hline $\begin{array}{l}\text { Development depends on } \\
\text { animals, not applicable for all } \\
\text { targets. For haptens, coupling to } \\
\text { a carrier is necessary. }\end{array}$ & $\begin{array}{l}\text { Identification via in vitro } \\
\text { selection techniques, applicable } \\
\text { for virtually all types of targets. }\end{array}$ & $\begin{array}{l}\text { Aptamers can be used as recognition elements for virtually all types } \\
\text { of targets like toxic or non-immunogenic substances including small } \\
\text { molecules. }\end{array}$ \\
\hline $\begin{array}{l}\text { In vivo production results in high } \\
\text { costs and batch-to-batch } \\
\text { variations. }\end{array}$ & $\begin{array}{l}\text { Chemical synthesis allows more } \\
\text { cost-effective production with } \\
\text { high reproducibility. }\end{array}$ & $\begin{array}{l}\text { Costs of aptasensors can be reduced, high quality ensured by } \\
\text { chemical synthesis. }\end{array}$ \\
\hline $\begin{array}{l}\text { Modification (e.g. with linkers, } \\
\text { dyes) takes place at random } \\
\text { positions. }\end{array}$ & $\begin{array}{l}\text { During synthesis, modifications } \\
\text { can be introduced at defined } \\
\text { positions. }\end{array}$ & $\begin{array}{l}\text { Controlled modification of aptamers enables controlled immobili- } \\
\text { zation and high activity of immobilized aptamers. Modification with } \\
\text { dyes facilitates the development of biosensors. }\end{array}$ \\
\hline $\begin{array}{l}\text { Recognize their target under } \\
\text { physiological/close to physiolog- } \\
\text { ical conditions. }\end{array}$ & $\begin{array}{l}\text { Conditions can be adopted in } \\
\text { order to generate aptamers active } \\
\text { under desired conditions. }\end{array}$ & $\begin{array}{l}\text { Aptasensors can be designed with recognition elements functional } \\
\text { under desired assay conditions with no need for sample preparation }\end{array}$ \\
\hline $\begin{array}{l}\text { Are highly conserved } \\
\text { biomolecules, different } \\
\text { antibodies behave similar. }\end{array}$ & $\begin{array}{l}\text { Are highly diverse in structure } \\
\text { and behavior. }\end{array}$ & Aptasensors need to be optimized for each individual aptamer. \\
\hline $\begin{array}{l}\text { Are sensitive to temperature, } \\
\text { denaturation is irreversible. }\end{array}$ & $\begin{array}{l}\text { Are stable against temperature, } \\
\text { denaturation is reversible. }\end{array}$ & Aptasensors can be used in a wide range of assay conditions. \\
\hline $\begin{array}{l}\text { Shelf life is limited; regeneration } \\
\text { may result in a loss of activity. }\end{array}$ & $\begin{array}{l}\text { Long shelf life; regeneration can } \\
\text { be performed without affecting } \\
\text { activity. }\end{array}$ & $\begin{array}{l}\text { Aptasensors are stable for extended periods of time and can be } \\
\text { regenerated. }\end{array}$ \\
\hline $\begin{array}{l}\text { High molecular weight } \\
(\sim 150 \mathrm{kDa} \text { for } \mathrm{IgG}) .\end{array}$ & $\begin{array}{l}\text { Low molecular weight } \\
(13-26 \mathrm{kDa}) \text {. }\end{array}$ & $\begin{array}{l}\text { Aptamers can be immobilized in high density resulting in a broad } \\
\text { dynamic range of the sensor. }\end{array}$ \\
\hline
\end{tabular}

In most cases, aptamers are reported to bind their targets via adaptive binding [12]. During the approximation of aptamer and target, the aptamer undergoes conformational reorganization in order to maximize interactions with the target. These conformational changes can be used to detect the binding events (further described in Section 3.1).

Based on their oligonucleotide nature and their generation by in vitro selection, aptamers offer some major advantages over their amino acid-based counterparts (Table 1). While the development of antibodies depends on the immunization of animals, aptamers are selected by in vitro techniques. Small molecules (haptens) are usually non-immunogenic and do not induce an immune response unless coupled with macromolecules (carriers) such as proteins [13]. In contrast, aptamers can be selected for virtually all types of targets including those with high toxicity or low immunogenicity, which qualifies them especially as binders for small target molecules.

Moreover, as the identification of antibodies is performed under in vivo conditions, the use of antibodies is restricted to conditions similar or close to physiological conditions. For aptamers, the in vitro selection can be performed under non-physiological con- ditions in order to generate aptamers that are functional under certain conditions. Thus, in the case of aptamers, a tailor-made affinity ligand can be obtained that is optimized for a certain application, e.g. an analytical problem [7]. While the possibility to select aptamers under varying conditions is advantageous for the detection of the target in its natural environment (e.g. in environmental and food samples) it may be problematic for the general design of aptamer-based assays. Since different aptamers are selected under different conditions, and need these conditions to maintain their functionality, general procedures for aptamer-based assays are hard to define. For example, the aptamer's selection buffer may be incompatible with the chemistry used to immobilize the aptamers [14]. Moreover, aptamers are very diverse in their composition (DNA, RNA), length (25- 120 nucleotides), and structural features (e.g. Gquadruplexes, three-dimensional folding). This diversity complicates the transfer of an established aptamerbased assay from one aptamer to another and necessitates the optimization of the assay for each aptamer. In contrast, antibodies are highly conserved biomolecules enabling straightforward transfer of antibody-based assays. 

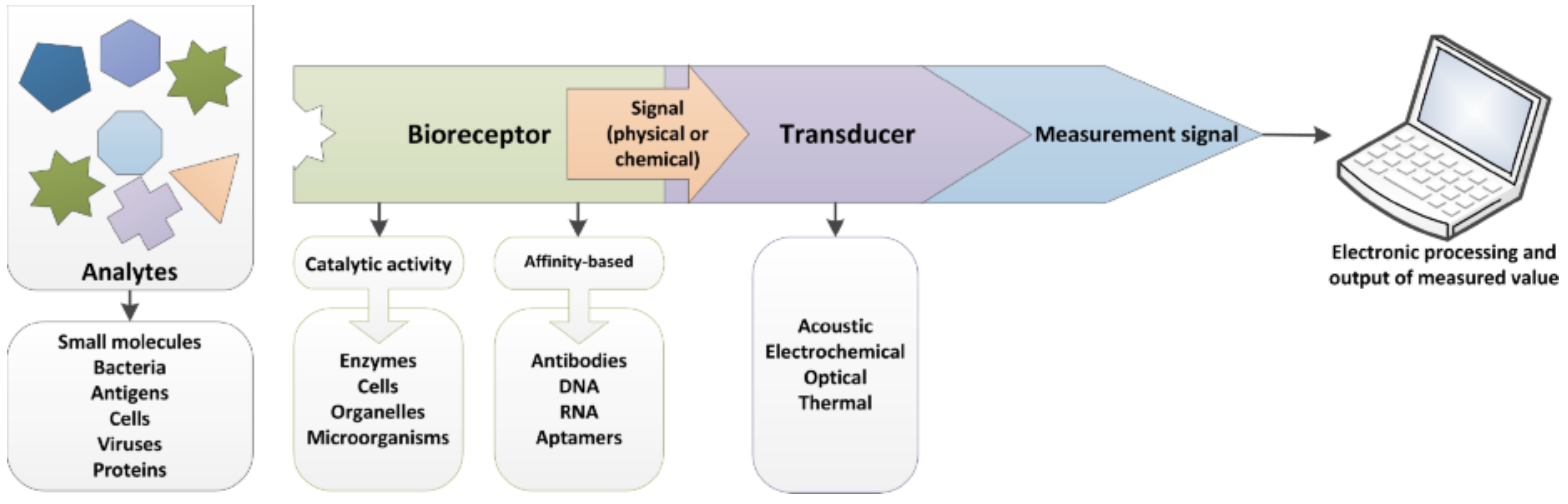

Fig. 2 (color online). Schematic illustration of a biosensor.

Once selected and sequenced, aptamers can be produced by chemical synthesis resulting in high reproducibility. In contrast, the production of antibodies depends on cell culture techniques, which may be a source of batch-batch variations. Moreover, during synthesis of aptamers modifications like linkers can be introduced at precise positions of the aptamer facilitating the immobilization on sensor surfaces or the incorporation of reporter groups for detection. Another major advantage of aptamers is their high stability. As oligonucleotides, they can undergo denaturation, but in contrast to antibodies, this denaturation is reversible. They can be easily regenerated and are stable to longterm storage. Because of their high affinity and specificity in combination with substantial advantages over conventional affinity ligands, aptamers are beginning to rival antibodies in many techniques based on molecular recognition including their use as affinity elements in biosensors [7]. The use of aptamers can extend the use of biosensors to the detection of targets not accessible by antibodies. Besides the obvious advantages of aptamers, there are some concerns about the stability of aptamers against nucleases present in biological fluids. This problem can be easily overcome by the use of nuclease-resistant aptamers, $e$. $g$. by post-SELEX modifications of the aptamer [15].

\section{Aptasensors for Small Molecule Detection}

Biosensors are able to transform chemical information, like the concentration of an analyte, into a detectable signal. A typical biosensor is composed of a biological recognition element immobilized on a transducer (Fig. 2). The transducer converts the binding event into a signal dependent on the concentration of the analyte. The recognition component of the biosensor binds to the analyte by molecular recognition. Thus, the sensitivity and specificity of the sensor are driven by the binding properties of this component.

Conventional recognition components include antibodies and enzymes. These protein-based recognition elements exhibit some disadvantages. E. g., for a given analytical problem, a suitable enzyme may not be available. In case of antibodies, there are several analytes against which antibodies are difficult to raise. This is especially true for toxic and non-immunogenic targets including many small molecules. Moreover, proteins like antibodies or enzymes are sensitive to degradation, which limits the shelf-life and the use of the biosensor under non-physiological conditions.

More recently, aptamers have been used as recognition elements; these types of biosensors have been termed "aptasensors" [17, 18]. Aptasensors have already been described for the detection of small molecules [19], proteins [20-22], and microorganisms [23]. Here, aptamers are used as biological recognition elements and offer several advantages over antibodies (Table 1). Aptamers enable the application of detection methods usually applied in antibody-based biosensors including sandwich-based and competitive assays [24].

Besides this simple substitution of antibodies by aptamers, aptamers enable the development of completely new sensor strategies. Especially two features of aptamers facilitate their use as novel intelligent biological recognition elements in biosensors: 
1. Most aptamers undergo conformational changes during target binding. These changes can be exploited to design sensing strategies.

2. Since aptamers are oligonucleotides, it is possible to design complementary oligonucleotides that hybridize with the aptamer. Competitive displacement of these complementary oligonucleotides by the target can be used to sense target binding.

Based on these general considerations, Han et al. have classified four different types of aptasensors according to the used mode of detection [24]:

(i) target-induced structure switching mode (TISS),

(ii) target-induced dissociation mode (TID),

(iii) competitive replacement, and

(iv) sandwich or sandwich-like mode.

In the following paragraphs, we will elucidate the different modes of detection and give examples for corresponding sensors with focus on the detection of small molecules. The principles of signal generation will be explained, and some examples are given to illustrate the underlying mechanisms. A more comprehensive overview of the current literature is given in Table 2.

\subsection{Aptasensors based on target-induced structure switching}

According to the induced fit mechanism, the binding of the target results in conformational changes of the aptamer. In the target-induced structure switching (TISS) mode, these conformational changes are used to generate a detectable signal [24]. The TISS strategy has been widely used in electrochemical aptasensors (Fig. 3). Here, the aptamers are covalently attached to an electrode surface via one of the aptamer termini, while the other terminus is modified with an electrochemically active redox compound like methylene blue or ferrocene. In the absence of the target, the redox compound is positioned far away from the surface resulting in no detectable signal. In the presence of the target, the aptamer adopts a folded conformation and the distance between the redox compound and the electrode surface decreases resulting in an electrochemical signal. Within this sensor concept, the electrochemical signal increases with increasing concentration of target (signal-on sensor). Since many aptamers contain partially folded structural elements even in the absence of the target, the TISS approach may not lead to sufficient signal intensities for

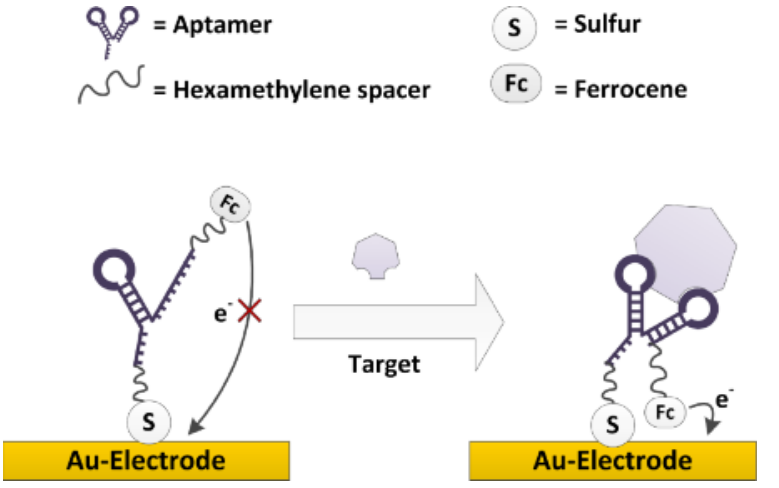

Fig. 3 (color online). Aptamer-based electrochemical sensing involving target-induced structure switching (TISS) of the aptamer. Modified from Willner and Zayats [28].

all native aptamers. Therefore, White et al. have investigated different methods to enhance the target-induced structural changes. Here, the destabilization of the native aptamer folding (in the absence of the target) results in signal enhancement and allows the detection of ATP [25].

One other example for the TISS mode is the socalled aptamer beacon [26]. Here one of the aptamer's termini is covalently modified with a fluorophore while the other terminus is modified with a quencher molecule. When fluorophor and quencher are in close proximity to each other, the signal emitted by the fluorophore is quenched. Stojanovic et al. have constructed an aptamer beacon based on an aptamer directed against cocaine. In the absence of cocaine, the fluorophore and the quencher were distant to each other. The binding of cocaine induces a structural rearrangement of the aptamer including the formation of a stem formed by the termini of the aptamer. Thus, the quencher could quench the fluorescence in the presence of the target, resulting in a signal-off sensor for cocaine [27].

\subsection{Aptasensors based on target-induced dissociation}

In the target-induced dissociation or displacement (TID) mode [24], aptamers are immobilized on the sensors' surface. Oligonucleotides complementary to the aptamers sequence bind to the aptamer via hybridization to form a duplex. In the presence of the target, the aptamer forms a complex with the target, and the complementary oligonucleotide dissociates from the immobilized duplex. For example, this dissocia- 
Table 2. Aptasensors for the detection of small molecules. TISS: target-induced structure switching, TID: target-induced dissociation, TIR: target-induced reassembly of aptamer fragments.

\begin{tabular}{|c|c|c|c|c|c|c|c|}
\hline $\begin{array}{l}\text { Design } \\
\text { strategy }\end{array}$ & Mode of detection & Target & LOD & $\begin{array}{l}\text { Dynamic } \\
\text { range }\end{array}$ & Sample & Comments & Reference \\
\hline TISS & Electrochemical & Cocaine & & & $\begin{array}{l}\text { Undiluted } \\
\text { fetal calf } \\
\text { serum, undi- } \\
\text { luted blood }\end{array}$ & $\begin{array}{l}\text { Regeneration of sen- } \\
\text { sor by washing with } \\
\text { serum lacking cocaine }\end{array}$ & $\begin{array}{l}\text { Swensen } \\
\text { et al. } \\
(2009)[47]\end{array}$ \\
\hline TISS & Electrochemical & ATP & & $25-250000 \mu \mathrm{M}$ & Tris buffer & Reagentless sensor & $\begin{array}{l}\text { White et al. } \\
\text { (2010) [25] }\end{array}$ \\
\hline$\overline{T I S S}$ & $\begin{array}{l}\text { Optical } \\
\text { (colorimetric) }\end{array}$ & Adenosine & & $20-2000 \mu \mathrm{M}$ & & $\begin{array}{l}\text { Based on stabiliza- } \\
\text { tion of AuNPs by } \\
\text { folded aptamer target } \\
\text { complexes }\end{array}$ & $\begin{array}{l}\text { Zhao et al. } \\
(2008)[48]\end{array}$ \\
\hline TISS & Electrochemical & Cocaine & $0.3 \mu \mathrm{M}$ & $1-150 \mu \mathrm{M}$ & $\begin{array}{l}\text { Phosphate- } \\
\text { buffered } \\
\text { saline, di- } \\
\text { luted serum }\end{array}$ & $\begin{array}{l}\text { Regeneration of sensor } \\
\text { by heat denaturation }\end{array}$ & $\begin{array}{l}\text { Hua et al. } \\
(2010)[33]\end{array}$ \\
\hline$\overline{T I S S}$ & $\begin{array}{l}\text { Optical } \\
\text { (colorimetric) }\end{array}$ & $\begin{array}{l}\text { Oxytetra- } \\
\text { cycline }\end{array}$ & $0.025 \mu \mathrm{M}$ & $\begin{array}{l}0.025-1 \mu \mathrm{M} \\
\text { (linear range) }\end{array}$ & Tris buffer & $\begin{array}{l}\text { Aggregation of AuNPs } \\
\text { leading to color change }\end{array}$ & $\begin{array}{l}\text { Kim et al. } \\
(2010)[49]\end{array}$ \\
\hline TISS & Electrochemical & Cocaine & $\begin{array}{l}<10 \mu \mathrm{M}, \\
500 \mu \mathrm{M} \text { (in diluted } \\
\text { fetal calf serum, } \\
\text { human saliva) }\end{array}$ & & $\begin{array}{l}\text { Diluted fetal } \\
\text { calf serum, } \\
\text { human saliva }\end{array}$ & $\begin{array}{l}\text { Regeneration via a brief } \\
\text { washing at r. t. }\end{array}$ & $\begin{array}{l}\text { Baker et al. } \\
(2006)[50]\end{array}$ \\
\hline TISS & $\begin{array}{l}\text { Optical } \\
\text { (electrochemi- } \\
\text { luminescence) }\end{array}$ & ATP & $0.006 \mu \mathrm{M}$ & $0.018-90.72 \mu \mathrm{M}$ & $\begin{array}{l}\text { Phosphate } \\
\text { buffered } \\
\text { saline }\end{array}$ & & $\begin{array}{l}\text { Huang et al. } \\
(2010)[51]\end{array}$ \\
\hline TISS & Electrochemical & Cocaine & $0.5 \mu \mathrm{M}$ & $1-15 \mu \mathrm{M}$ & $\begin{array}{l}\text { Phosphate- } \\
\text { buffered } \\
\text { saline }\end{array}$ & $\begin{array}{l}\text { Regeneration with Tris } \\
\text { buffer }\end{array}$ & $\begin{array}{l}\text { Li et al. } \\
(2008)[52]\end{array}$ \\
\hline TISS & Electrochemical & $\begin{array}{l}\text { Tetra- } \\
\text { cycline }\end{array}$ & $0.01 \mu \mathrm{M}$ & $0.01-10 \mu \mathrm{M}$ & Tris buffer & & $\begin{array}{l}\text { Kim et al. } \\
(2010)[53]\end{array}$ \\
\hline TISS & $\begin{array}{l}\text { Optical } \\
\text { (fluorescence) }\end{array}$ & Cocaine & & $12.5-1500 \mu \mathrm{M}$ & $\begin{array}{l}\text { Tris buffer, } \\
\text { human } \\
\text { serum }\end{array}$ & $\begin{array}{l}\text { Signalling aptamer/ } \\
\text { aptamer beacon }\end{array}$ & $\begin{array}{l}\text { Stojanovic } \\
\text { et al. } \\
(2001)[27] \\
\end{array}$ \\
\hline TID & Electrochemical & ATP & $0.01 \mu \mathrm{M}$ & $0.01-1000 \mu \mathrm{M}$ & Lysed cells & & $\begin{array}{l}\text { Zuo et al. } \\
(2007)[30]\end{array}$ \\
\hline TID & $\begin{array}{l}\text { Optical (chemi- } \\
\text { luminescence) }\end{array}$ & Cocaine & $0.00048 \mu \mathrm{M}$ & $\begin{array}{l}0.001-0.01 \mu \mathrm{M} \\
\text { (linear range) }\end{array}$ & $\begin{array}{l}\text { Phosphate- } \\
\text { buffered } \\
\text { saline }\end{array}$ & & $\begin{array}{l}\text { Li et al. } \\
(2011)[32]\end{array}$ \\
\hline TID & Electrochemical & Adenosine & $0.00002 \mu \mathrm{M}$ & $0.00002-0.02 \mu \mathrm{M}$ & Tris buffer & $\begin{array}{l}\text { Bifunctional sensor for } \\
\text { adenosine and lysozyme }\end{array}$ & $\begin{array}{l}\text { Deng et al. } \\
(2009)[54]\end{array}$ \\
\hline TID & Electrochemical & Adenosine & $0.000002 \mu \mathrm{M}$ & & & & $\begin{array}{l}\text { Zayats et al. } \\
(2006)[55]\end{array}$ \\
\hline TID & $\begin{array}{l}\text { Chronocoulo- } \\
\text { metric }\end{array}$ & $\begin{array}{l}\text { Adenosine } \\
\text { monophos- } \\
\text { phate }\end{array}$ & $0.1 \mu \mathrm{M}$ & $0.1-1000 \mu \mathrm{M}$ & & & $\begin{array}{l}\text { Shen et al. } \\
(2007)[56]\end{array}$ \\
\hline TID & Electrochemical & ATP & & $\begin{array}{l}0.01-0.08 \mu \mathrm{M} \\
\text { (linear range) }\end{array}$ & Tris buffer & $\begin{array}{l}\text { Regeneration by heat } \\
\text { denaturation }\end{array}$ & $\begin{array}{l}\text { Lu } \text { et al. } \\
(2008)[57]\end{array}$ \\
\hline TID & Electrochemical & Adenosine & $1 \mu \mathrm{M}$ & $1-1000 \mu \mathrm{M}$ & & $\begin{array}{l}\text { Regeneration by rehy- } \\
\text { bridizing ATP-binding } \\
\text { aptamer with comple- } \\
\text { mentary strand }\end{array}$ & $\begin{array}{l}\text { Li et al. } \\
(2007)[58]\end{array}$ \\
\hline TID & Electrochemical & Adenosine & $\begin{array}{l}0.001 \mu \mathrm{M} \\
\text { (estimated) }\end{array}$ & $\begin{array}{l}0.005-1 \mu \mathrm{M} \\
\text { (linear regression } \\
\text { curve) }\end{array}$ & & $\begin{array}{l}\text { Regeneration by im- } \\
\text { mersing the electrode } \\
\text { in adenosine aptamer } \\
\text { solution }\end{array}$ & $\begin{array}{l}\text { Feng et al. } \\
(2008)[59]\end{array}$ \\
\hline
\end{tabular}


Table 2. (Continued.)

\begin{tabular}{|c|c|c|c|c|c|c|c|}
\hline $\begin{array}{l}\text { Design } \\
\text { strategy }\end{array}$ & Mode of detection & Target & LOD & $\begin{array}{l}\text { Dynamic } \\
\text { range }\end{array}$ & Sample & Comments & Reference \\
\hline TID & Electrochemical & Adenosine & $0.01 \mu \mathrm{M}$ & $0.01-2 \mu \mathrm{M}$ & $\begin{array}{l}\text { Phosphate- } \\
\text { buffered } \\
\text { saline }\end{array}$ & $\begin{array}{l}\text { Regeneration by hy- } \\
\text { bridizing the aptamer } \\
\text { with complementary } \\
\text { oligonucleotide }\end{array}$ & $\begin{array}{l}\text { Wang et al. } \\
(2009)[60]\end{array}$ \\
\hline TID & $\begin{array}{l}\text { Optical } \\
\text { (colorimetric) }\end{array}$ & $\begin{array}{l}\text { Adenosine, } \\
\text { Cocaine }\end{array}$ & $\begin{array}{l}20 \mu \mathrm{M} \\
\text { (Adenosine) } \\
10 \mu \mathrm{M} \\
\text { (Cocaine) }\end{array}$ & & $\begin{array}{l}\text { Tris-acetate buffer, } \\
\text { untreated human } \\
\text { blood serum } \\
\text { (cocaine) }\end{array}$ & $\begin{array}{l}\text { Lateral flow } \\
\text { technology, } \\
\text { "dipsticks" }\end{array}$ & $\begin{array}{l}\text { Liu et al. } \\
(2006)[61]\end{array}$ \\
\hline TID & $\begin{array}{l}\text { Optical } \\
\text { (interferometry) }\end{array}$ & ATP & $400 \mu \mathrm{M}$ & $400-1500 \mu \mathrm{M}$ & Tris buffer & & $\begin{array}{l}\text { Carrasquilla } \\
\text { et al. }(2011) \\
{[29]}\end{array}$ \\
\hline TID & Electrochemical & ATP & $0.0001 \mu \mathrm{M}$ & $0.0001-0.1 \mu \mathrm{M}$ & Tris buffer & & $\begin{array}{l}\text { Du et al. } \\
\text { (2009) [62] }\end{array}$ \\
\hline TID & $\begin{array}{l}\text { Optical (SPR } \\
\text { spectroscopy) }\end{array}$ & Adenosine & & $0.00001-0.1 \mu \mathrm{M}$ & Tris buffer & & $\begin{array}{l}\text { Wang et al. } \\
\text { (2009) [63] }\end{array}$ \\
\hline TID & $\begin{array}{l}\text { Optical (surface- } \\
\text { enhanced Raman } \\
\text { scattering) }\end{array}$ & Adenosine & $0.01 \mu \mathrm{M}$ & $0.02-2 \mu \mathrm{M}$ & $\begin{array}{l}\text { Phosphate- } \\
\text { buffered } \\
\text { saline }\end{array}$ & $\begin{array}{l}\text { Regeneration by } \\
\text { heat denaturation }\end{array}$ & $\begin{array}{l}\text { Chen et al. } \\
(2008)[64]\end{array}$ \\
\hline TID & Electrochemical & ATP & $0.01 \mu \mathrm{M}$ & $0.01-100 \mu \mathrm{M}$ & & $\begin{array}{l}\text { Parallel detection of } \\
\text { ATP and } \alpha \text {-thrombin }\end{array}$ & $\begin{array}{l}\text { Du et al. } \\
(2008)[65]\end{array}$ \\
\hline TID & $\begin{array}{l}\text { Optical (flow } \\
\text { cytometry) }\end{array}$ & Adenosine & $\begin{array}{l}178 \mu \mathrm{M} \\
\text { (in buffer) } \\
167 \mu \mathrm{M} \text { (in } \\
30 \% \text { serum) }\end{array}$ & & $\begin{array}{l}\text { HEPES buffer, } \\
\text { diluted human } \\
\text { blood serum }\end{array}$ & & $\begin{array}{l}\text { Huang et al. } \\
(2010)[66]\end{array}$ \\
\hline $\begin{array}{l}\text { Competitive } \\
\text { replacement }\end{array}$ & $\begin{array}{l}\text { Impedimetric } \\
\text { (Faradaic } \\
\text { impedance } \\
\text { spectroscopy) }\end{array}$ & Neomycin B & & $\begin{array}{l}0.75-500 \mu \mathrm{M} \\
\text { (in buffer) } \\
25-2500 \mu \mathrm{M} \\
\text { (in diluted milk) }\end{array}$ & $\begin{array}{l}\text { Tris buffer, } \\
\text { diluted milk }\end{array}$ & $\begin{array}{l}\text { Regeneration with } \\
\text { highly concentrated } \\
\text { saline solution, } \\
\text { neomycin B solution }\end{array}$ & $\begin{array}{l}\text { de-los-San- } \\
\text { tos-Álvarez } \\
(2007)[34]\end{array}$ \\
\hline Sandwich & Electrochemical & $\begin{array}{l}\text { Sodium } \\
\text { diclofenac }\end{array}$ & $0.27 \mu \mathrm{M}$ & $\begin{array}{l}0-5 \mu \mathrm{M} \\
10-1000 \mu \mathrm{M} \\
\text { (two different } \\
\text { linear ranges) }\end{array}$ & $\begin{array}{l}\text { Human blood } \\
\text { serum }\end{array}$ & & $\begin{array}{l}\text { Kashefi- } \\
\text { Kheyrabadi } \\
(2012)[67]\end{array}$ \\
\hline Sandwich & $\begin{array}{l}\text { Optical (light } \\
\text { scattering) }\end{array}$ & $\begin{array}{l}\text { Oxytetra- } \\
\text { cycline }\end{array}$ & $100 \mathrm{ppb}$ & $100-10^{4} \mathrm{ppb}$ & $\begin{array}{l}\text { Phosphate-buffered } \\
\text { saline }\end{array}$ & & $\begin{array}{l}\text { Kim et al. } \\
(2010)[68]\end{array}$ \\
\hline$\overline{\text { TIR }}$ & Electrochemical & Cocaine & $0.1 \mu \mathrm{M}$ & $0.1-38.8 \mu \mathrm{M}$ & $\begin{array}{l}\text { Tris buffer, human } \\
\text { plasma, serum, } \\
\text { saliva, urine }\end{array}$ & & $\begin{array}{l}\text { Du et al. } \\
(2010)[69]\end{array}$ \\
\hline$\overline{\text { TIR }}$ & $\begin{array}{l}\text { Optical } \\
\text { (fluorescence) }\end{array}$ & $\begin{array}{l}\text { Cocaine } \\
\text { ATP }\end{array}$ & $\begin{array}{l}0.1 \mu \mathrm{M} \\
(\text { Cocaine }) \\
0.2 \mu \mathrm{M} \\
\text { (ATP) }\end{array}$ & $\begin{array}{l}0.5-1000 \mu \mathrm{M} \text { (lin- } \\
\text { ear range, cocaine) } \\
1-1000 \mu \mathrm{M} \\
\text { (linear range, ATP) }\end{array}$ & Phosphate buffer & & $\begin{array}{l}\text { Zhou et al. } \\
(2011)[40]\end{array}$ \\
\hline$\overline{\mathrm{TIR}}$ & $\begin{array}{l}\text { Optical } \\
\text { (colorimetric) }\end{array}$ & $\begin{array}{l}\text { Adenosine } \\
\text { Cocaine }\end{array}$ & $\begin{array}{l}250 \mu \mathrm{M} \\
\text { (Adenosine) } \\
100 \mu \mathrm{M} \\
\text { (Cocaine) }\end{array}$ & $250-1000 \mu \mathrm{M}$ & Tris buffer & & $\begin{array}{l}\text { Li et al. } \\
(2009)[39]\end{array}$ \\
\hline TISS & $\begin{array}{l}\text { Optical } \\
\text { (colorimetric) }\end{array}$ & $\begin{array}{l}\text { ATP, } \\
\text { Cocaine }\end{array}$ & $5 \mu \mathrm{M}$ & & HEPES buffer & $\begin{array}{l}\text { Aptamer-DNAzyme } \\
\text { cascade }\end{array}$ & $\begin{array}{l}\text { Elbaz et al. } \\
(2009)[70]\end{array}$ \\
\hline
\end{tabular}

tion can be detected optically by modification of the aptamer with a fluorophore and the complementary oligonucleotide with a quencher (Fig. 4). For regeneration of the TID-based sensor, the aptamer-modified sensor can be re-incubated with the complementary oligonucleotide [29].
This duplex-to-aptamer approach has been used for electrochemical detection of ATP by Zuo et al. Here, the ferrocene-modified aptamer was immobilized on the gold surface of the sensor and hybridized with a complementary oligonucleotide to form a duplex. Due to the rigid structure of the duplex, the "off" 

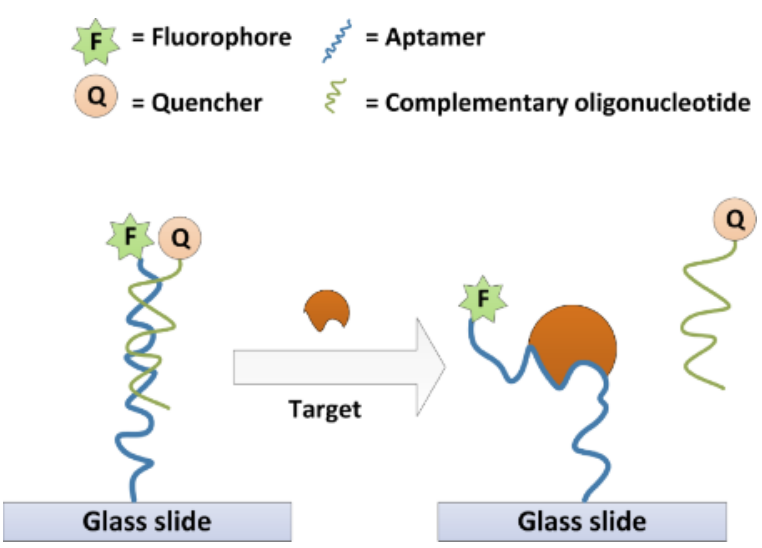

Fig. 4 (color online). Aptamer-based optical sensing involving target-induced dissociation (TID) of a complementary oligonucleotide from the aptamer. Modified from Tuleuova et al. [31].

state of the sensor is well-defined with the ferrocene positioned far away from the sensor surface (approx. $10 \mathrm{~nm})$. In the presence of ATP the aptamer forms a complex with the target, and the complementary oligonucleotide is released from the duplex. Within the aptamer-target complex, the ferrocene comes into close proximity to the sensor surface in the "on" state of the sensor resulting in an electrochemical signal [30].

Li et al. have used TID to create a chemiluminescence sensor for cocaine detection. Here, the aptamer is immobilized on magnetic beads. A complementary oligonucleotide was immobilized on gold nanoparticles, which were also modified with horseradish peroxidase. In the absence of cocaine, a duplex is formed by the aptamer and the complementary oligonucleotide, and the addition of cocaine induces the release of the double-functional gold nanoparticles. After magnetic separation, the liberated gold nanoparticles were incubated with luminol, $p$-iodophenol and $\mathrm{H}_{2} \mathrm{O}_{2}$ resulting in the detection of a chemiluminescence signal. This sensor shows very good sensitivity (LOD $480 \mathrm{pM}$ ) which has been assumed to be a result of the gold nanoparticle loading with several peroxidase molecules [32].

\subsection{Aptasensors based on competitive replacement}

In aptasensors based on competitive replacement [33], the aptamer is immobilized on the sensor surface. Before the measurement of the analyte, the labelled target is bound to the aptamer. Non-labelled tar-
$\sum_{S}^{3}$

= Mercaptopropionic acid spacer $\quad=$ Aptamer

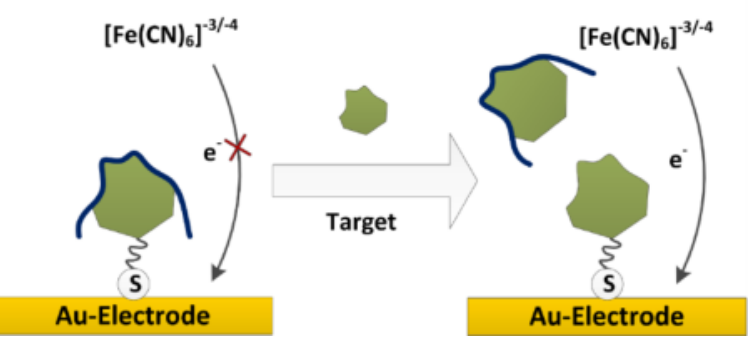

Fig. 5 (color online). Aptamer-based electrochemical sensing involving competitive replacement of the aptamer from the immobilized target. Modified from de-los-Santos-Alvarez et al. [34].

get molecules present in the sample competively bind to the aptamer resulting in a displacement of bound target. It is also possible to immobilize the target on the surface and bind the aptamer to the immobilized target (Fig. 5). In the context of small molecule detection, this approach has been used to detect neomycin B. Neomycin B was immobilized on the sensor surface, and an aptamer directed against neomycin was bound to the immobilized target. The presence of neomycin in the sample resulted in the competitive binding of the free neomycin to the aptamer and a release of the aptamer from the immobilized target which could be detected by Faradaic impedance spectroscopy or SPR [34, 35].

\subsection{Aptasensors of sandwich-type}

Within the sandwich mode, one aptamer directed against the target is immobilized on the sensors surface. The target binds to this immobilized aptamer, and detection is performed by binding of a second aptamer (Fig. 6). Therefore, the target has to contain at least two distinct binding sites for aptamers. While the sandwich mode is widely applied to protein detection [36-38], it is limited for small molecule detection. In case of aptamers directed against small molecules, the target is often completely embedded into the aptamers structure. Thus, the bound target provides no more space for the binding of a second aptamer.

Nonetheless, White et al. have designed an electrochemical "pseudo-sandwich" aptamer-based sensor 


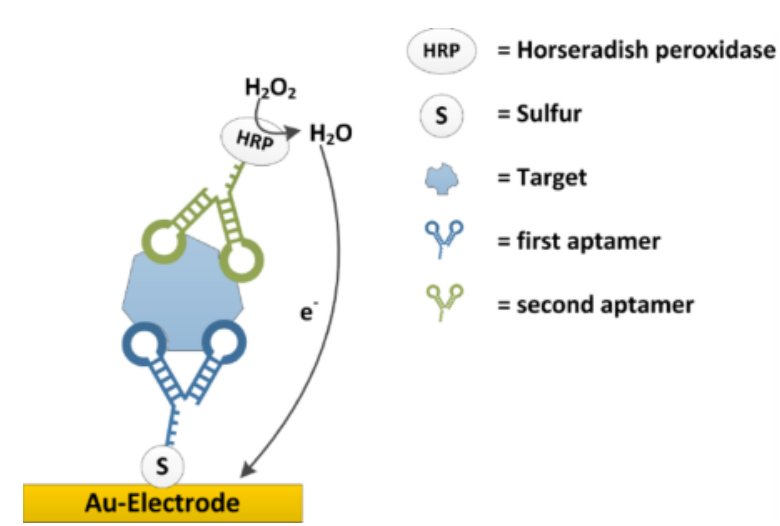

Fig. 6 (color online). Aptamer-based electrochemical sensing based on sandwich-like binding of two aptamers to one target molecule. Modified from Willner and Zayats [28].

for the detection of ATP by separating the aptamer directed against ATP into two parts utilizing an internal polythymine linker. Here, the binding of the target induces the association of the separated domains of the aptamer [25]. Consequently, in the classification according to Han et al. [24], this sensor rather belongs to the TISS mode than to real sandwich mode sensors.

\subsection{Aptasensors based on target-induced reassembly of aptamer fragments}

In addition to the four sensor concepts described by Han et al. [24], we have identified a novel sensor principle based on the unique structural properties of aptamers. This design is based on the target-induced rearrangement of aptamer fragments (TIR, Fig. 7).
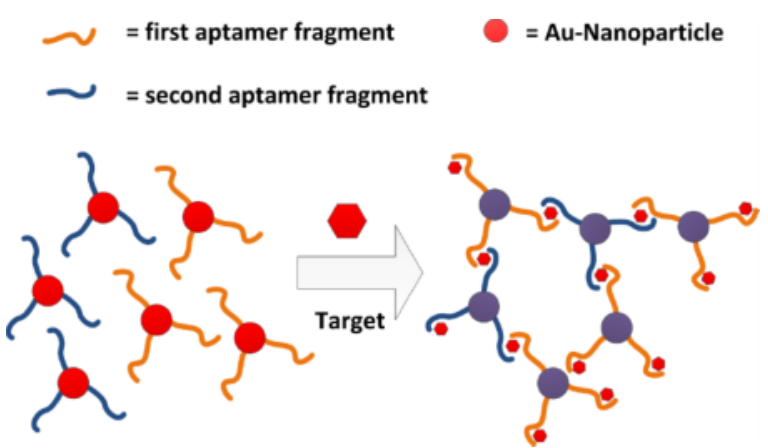

Fig. 7 (color online). Aptamer-based optical sensing based on target-induced reassembly of aptamer fragments (TIR). Modified from Li et al. [39].
Here, the aptamer is divided into two parts that do not interact with each other in the absence of the target. In the presence of the target, the two fragments reassemble to form a three-molecular complex with the target. This method was employed, for example, by Zhou et al. to design an aptasensor for the detection of cocaine. Here, the reassembly of the aptamer fragments was detected by modifying the fragments with silver nanoclusters (NC), which show an increase in fluorescence at decreasing distances of Ag NCs [40].

\section{Current Limitations and Future Perspectives}

As elaborated above, aptasensors can be designed in different formats to enable the detection of small molecules using different techniques for sensing. Nonetheless, the summary of the literature given in Table 2 reveals that aptasensors have been used only for the detection of few small molecules yet. Most of the aptasensors described in the literature were used for the detection of adenosine, ATP, and cocaine, and only few reports on other analytes were found.

Since plenty of aptamers directed against diverse small molecules have already been published [41, 42], this restriction of aptasensors to mainly three analytes is quite surprising. Within the young and further developing field of aptasensors, many researchers have focused on the well-characterized aptamers directed against ATP and cocaine for the development of aptasensors, and other targets will likely follow in the near future.

Another concern that may arise regarding aptamers is their relatively costly production. In this context, we expect the prices of oligonucleotides to decrease. This process is further driven by the development of pharmaceutical oligonucleotides. The first aptamer-based therapeutic (Pegaptanib) has been approved in 2004 for the treatment of age-related macular degeneration [43], and in 2009 the number of oligonucleotide therapeutic programs has increased to $231[44,45]$. This progress accelerates the development of more economic methods for the large-scale synthesis of highquality oligonucleotides [46].

\section{Summary and Conclusion}

It has been demonstrated that aptasensors can be used for the sensitive and specific detection of small molecules even in complex samples. Many different 
formats with varying read-out techniques have already been applied successfully. Aptamers seem to be ideal biological recognition elements for the design of intelligent sensors based on their specific properties. Especially the fact that most aptamers undergo conformational changes during the binding of the target is a basis for novel sensor strategies. Moreover, due to their oligonucleotide nature, it is possible to rationally design novel sensing strategies involving oligonucleotides complementary to the aptamers sequence. Based on these outstanding advantages of aptamerbased biosensing, the use of aptasensors, which is yet limited to only few targets, will likely expand to the detection of further targets within the near future.
[1] X. Wang, S. Wang, Sensors 2008, 8, 6045-6054.

[2] K. You, S. Lee, A. Im, S. Lee, Biotechnol. Bioprocess Eng. 2003, 8, 64-75.

[3] C. Tuerk, L. Gold, Science 1990, 249, 505-510.

[4] D. L. Robertson, G. F. Joyce, Nature 1990, 344, $467-$ 468.

[5] A. D. Ellington, J. W. Szostak, Nature 1990, 346, 818 822 .

[6] R. Stoltenburg, C. Reinemann, B. Strehlitz, Anal. Bioanal. Chem. 2005, 383, $83-91$.

[7] S. D. Jayasena, Clin. Chem. 1999, 45, 1628-1650.

[8] D. Proske, M. Blank, R. Buhmann, A. Resch, Appl. Microbiol. Biotechnol. 2005, 69, 367-374.

[9] A. Nitsche, A. Kurth, A. Dunkhorst, O. Panke, H. Sielaff, W. Junge, D. Muth, F. Scheller, W. Stocklein, C. Dahmen, G. Pauli, A. Kage, BMC Biotechnol. 2007, 7, 48.

[10] M. Berezovski, A. Drabovich, S. M. Krylova, M. Musheev, V. Okhonin, A. Petrov, S. N. Krylov, J. Am. Chem. Soc. 2005, 127, 3165-3171.

[11] T. Hermann, D. J. Patel, Science 2000，287，820825.

[12] D. J. Patel, A. K. Suri, F. Jiang, L. Jiang, P. Fan, R. A. Kumar, S. Nonin, J. Mol. Biol. 1997, 272, 645-664.

[13] K. V. Singh, J. Kaur, G. C. Varshney, M. Raje, C. R. Suri, Bioconjug. Chem. 2004, 15, 168-173.

[14] J. G. Walter, O. Kokpinar, K. Friehs, F. Stahl, T. Scheper, Anal. Chem. 2008, 80, $7372-7378$.

[15] R. Stoltenburg, C. Reinemann, B. Strehlitz, Biomol. Eng. 2007, 24, $381-403$.

[16] J. G. Walter, F. Stahl, T. Scheper, Eng. Life Sci. 2012, doi:10.1002/elsc.201100197.

[17] C. K. O'Sullivan, Anal. Bioanal. Chem. 2002, 372, $44-48$.

[18] Y. C. Lim, A. Z. Kouzani, W. Duan, J. Biomed. Nanotechnol. 2010, 6, 93-105.

[19] M. Menger, J. Glökler, M. Rimmele in RNA Towards Medicine, (Eds.: V. Erdmann, J. Barciszewski, J. Brosius), Handb. Exp. Pharmacol. Vol. 173, 2006, pp. $359-373$.

[20] B. Strehlitz, N. Nikolaus, R. Stoltenburg, Sensors 2008, 8, 4296-4307.
[21] S. P. Song, L. H. Wang, J. Li, J. L. Zhao, C. H. Fan, TrAC, Trends Anal. Chem. 2008, 27, $108-117$.

[22] P. Hong, W. Li, J. Li, Sensors 2012, 12, 1181-1193.

[23] E. Torres-Chavolla, E. C. Alocilja, Biosens. Bioelectron. 2009, 24, 3175-3182.

[24] K. Han, Z. Liang, N. Zhou, Sensors 2010, 10, 4541 4557.

[25] R. J. White, A. A. Rowe, K. W. Plaxco, Analyst 2010, 135, 589-594.

[26] N. Hamaguchi, A. Ellington, M. Stanton, Anal. Biochem. 2001, 294, 126-131.

[27] M. N. Stojanovic, P. de Prada, D. W. Landry, J. Am. Chem. Soc. 2001, 123, 4928-4931.

[28] I. Willner, M. Zayats, Angew. Chem. Int. Ed. 2007, 46, $6408-6418$.

[29] C. Carrasquilla, Y. Xiao, C. Q. Xu, Y. Li, J. D. Brennan, Anal. Chem. 2011, 83, 7984-7991.

[30] X. Zuo, S. Song, J. Zhang, D. Pan, L. Wang, C. Fan, J. Am. Chem. Soc. 2007, 129, $1042-1043$.

[31] N. Tuleuova, C. N. Jones, J. Yan, E. Ramanculov, Y. Yokobayashi, A. Revzin, Anal. Chem. 2010, 82, $1851-1857$.

[32] Y. Li, X. Ji, B. Liu, Anal. Bioanal. Chem. 2011, 401, $213-219$.

[33] M. Hua, M. Tao, P. Wang, Y. Zhang, Z. Wu, Y. Chang, Y. Yang, Anal. Sci. 2010, 26, $1265-1270$.

[34] N. de-los-Santos-Álvarez, M. J. Lobo-Casta nón, A. J. Miranda-Ordieres, P. Tuñón-Blanco, J. Am. Chem. Soc. 2007, 129, $3808-3809$.

[35] N. de-los-Santos-Álvarez, M. J. Lobo-Casta nón, A. J. Miranda-Ordieres, P. Tuñón-Blanco, Biosens. Bioelectron. 2009, 24, $2547-2553$.

[36] J. Wang, W. Meng, X. Zheng, S. Liu, G. Li, Biosens. Bioelectron. 2009, 24, $1598-1602$.

[37] B. Li, Y. Wang, H. Wei, S. Dong, Biosens. Bioelectron. 2008, 23, 965-970.

[38] S. Centi, S. Tombelli, M. Minunni, M. Mascini, Anal. Chem. 2007, 79, 1466-1473.

[39] F. Li, J. Zhang, X. Cao, L. Wang, D. Li, S. Song, B. Ye, C. Fan, Analyst 2009, 134, 1355-1360.

[40] Z. Zhou, Y. Du, S. Dong, Biosens. Bioelectron. 2011, $28,33-37$. 
[41] M. Famulok, Curr. Opin. Struct. Biol. 1999, 9, $324-$ 329.

[42] H. Fickert, I. G. Fransson, U. Hahn in Aptamers to small molecules, (Ed.: S. Klussmann), VCH, Weinheim, 2006, chapter 4, pp. $95-113$.

[43] E. W. Ng, D. T. Shima, P. Calias, E. T. Cunningham, Jr., D. R. Guyer, A. P. Adamis, Nat. Rev. Drug. Discov. 2006, 5, 123 - 132 .

[44] V. Glaser, Genet. Eng. Biotechnol. News 2011, 31; available online: http://www.genengnews.com/genarticles/oligonucleotideproduction-gearing-up/3625/ (retrieved August 31, 2012).

[45] L. S. Green, C. Bell, N. Janjic, Biotechniques 2001, 30, 1094-1096, 1098, 1100.

[46] H. Aygün, Innovations Pharm. Technol. 2008, 25, $57-60$.

[47] J. S. Swensen, Y. Xiao, B. S. Ferguson, A. A. Lubin, R. Y. Lai, A. J. Heeger, K. W. Plaxco, H. T. Soh, J. Am. Chem. Soc. 2009, 131, $4262-4266$.

[48] W. Zhao, W. Chiuman, J. C. Lam, S. A. McManus, W. Chen, Y. Cui, R. Pelton, M. A. Brook, Y. Li, J. Am. Chem. Soc. 2008, 130, 3610-3618.

[49] Y. S. Kim, J. H. Kim, I. A. Kim, S. J. Lee, J. Jurng, M. B. Gu, Biosens. Bioelectron. 2010, 26, 16441649.

[50] B. R. Baker, R. Y. Lai, M. S. Wood, E. H. Doctor, A. J. Heeger, K. W. Plaxco, J. Am. Chem. Soc. 2006 , 128, 3138-3139.

[51] H. Huang, Y. Tan, J. Shi, G. Liang, J. J. Zhu, Nanoscale 2010, 2, 606-612.

[52] X. Li, H. Qi, L. Shen, Q. Gao, C. Zhang, Electroanalysis 2008, 20, 1475-1482.

[53] Y. Kim, Y. Kim, J. Niazi, M. Gu, Bioprocess Biosyst. Eng. 2010, 33, 31-37.
[54] C. Deng, J. Chen, L. Nie, Z. Nie, S. Yao, Anal. Chem. 2009, 81, 9972-9978.

[55] M. Zayats, Y. Huang, R. Gill, C. A. Ma, I. Willner, J. Am. Chem. Soc. 2006, 128, 13666-13667.

[56] L. Shen, Z. Chen, Y. Li, P. Jing, S. Xie, S. He, P. He, Y. Shao, Chem. Commun. 2007, 2169-2171.

[57] Y. Lu, X. Li, L. Zhang, P. Yu, L. Su, L. Mao, Anal. Chem. 2008, 80, 1883-1890.

[58] B. Li, Y. Du, H. Wei, S. Dong, Chem. Commun. 2007, $3780-3782$.

[59] K. Feng, C. Sun, Y. Kang, J. Chen, J. Jiang, G. Shen, R. Yu, Electrochem. Commun. 2008, 10, 531-535.

[60] J. Wang, F. Wang, S. Dong, J. Electroanal. Chem. 2009, $626,1-5$

[61] J. Liu, D. Mazumdar, Y. Lu, Angew. Chem. Int. Ed. 2006, 45, $7955-7959$.

[62] Y. Du, B. Li, F. Wang, S. Dong, Biosens. Bioelectron. 2009, 24, 1979-1983.

[63] J. Wang, A. Munir, H. S. Zhou, Talanta 2009, 79, $72-76$.

[64] J. W. Chen, X. P. Liu, K. J. Feng, Y. Liang, J. H. Jiang, G. L. Shen, R. Q. Yu, Biosens. Bioelectron. 2008, 24 , $66-71$.

[65] Y. Du, B. Li, H. Wei, Y. Wang, E. Wang, Anal. Chem. 2008, 80, 5110-5117.

[66] P. J. Huang, J. Liu, Anal. Chem. 2010, 82, 4020-4026.

[67] L. Kashefi-Kheyrabadi, M. A. Mehrgardi, Biosens. Bioelectron. 2012, 33, 184-189.

[68] K. Kim, M. Gu, D. Kang, J. Park, I. Song, H. Jung, K. Suh, Electrophoresis 2010, 31, 3115-3120.

[69] Y. Du, C. Chen, J. Yin, B. Li， M. Zhou， S. Dong, E. Wang, Anal. Chem. 2010, 82, 1556-1563.

[70] J. Elbaz, M. Moshe, B. Shlyahovsky, I. Willner, Chem. Eur. J. 2009, 15, $3411-3418$. 